\title{
USE OF ALUMINUM ALLOYS IN BRIDGE ENGINEERING - DECK SHAPE DESIGN
}

\author{
${ }^{1}$ Paweł Grzegorz KOSSAKOWSKI, ${ }^{2}$ Andrzej KRONER \\ Faculty of Civil Engineering and Architecture, Kielce University of Technology, Kielce, Poland, EU \\ 1Department of Strength of Materials and Concrete Structures, kossak@tu.kielce.pl \\ ${ }^{2}$ Department of Transportation Engineering, akroner@tu.kielce.pl
}

https://doi.org/10.37904/metal.2019.946

\begin{abstract}
The article aims at the use of lightweight aluminum alloy decks in bridge engineering and presents the advantages of their increasing application. The article also highlights the properties affecting the durability and compressibility of aluminum alloys. Next, the article covers the assets of the aluminum alloy box-section decks. Low weight, durability, resistance to operating conditions, fatigue life and ease of geometric shape design are the virtues that made them more commonly applied for bridges and footbridges. Difficult operating conditions and the complexity of stresses, the requirement for frequent inspections and maintenance, the diversity of dimensions as well as geometric and structural solutions in bridge engineering are behind the search for the latest solutions. Bridges, as strategic structures designed for transportation, forwarding and logistics, also require minimisation of traffic problems in the event of a lane shut-down for the time of repair. The use of prefabricated aluminum decks reduces load, time and energy consumption and improves working methods. The functional and light aluminum alloy decks, combinable with a durable polymer surface, create new possibilities for the shape design of the existing upgraded bridges. Overcoming the limitations of concrete and steel supporting structures allows replacing, enlarging, widening or even adding new road lanes. The environmental aspect of the use of recycled materials in production has also been raised here. The article presents concrete examples of renovation of the existing wooden, steel and reinforced concrete bridge structures with alternative aluminum alloy decks.
\end{abstract}

Keywords: Aluminum alloys, bridge decks system, renovation of bridge structures

\section{INTRODUCTION}

New solutions in investment optimization are constantly searched for civil engineering. This usually applies to construction solutions which make structures increasingly sophisticated and have a higher durability compared to structures constructed with traditional techniques. One of the industries that are looking for more advanced solutions, due to its new challenges, is bridge engineering. The evolution of bridges over the centuries mainly included the gradual introduction of new materials and consequently the development of structural systems. Bridges were basically made from all possible building materials and nowadays steel and concrete structures (reinforced concrete and pre-stressed concrete) are commonly used. They have their specificity, advantages and disadvantages, and the design and execution is closely related to the dimensions of structures. Difficult working conditions, especially at road bridges (stresses, exposure to environmental factors, etc.) adversely affect the service life. This is a serious problem and therefore the range of repair technologies, alternative materials, more effective protection methods and improved construction solutions are rapidly growing. The use of materials other than steel in bridge engineering, especially all aluminum alloys, is interesting with regard to metals. Although their use in this industry has already been present for some time now, aluminum alloys provide new possibilities due to a number of their advantageous features, such as for shaping bridge structures. Each of the deck types: reinforced concrete, metal and composite concrete has its specific type of damage. In case of metal bridges (steel, aluminum), these are mainly cracks and fatigue failures, usually formed in the so-called structural notches, i.e. usually welded joints between the deck elements [1]. These damages lead to a gradual loss of deck stiffness and cause rapid deterioration of the insulation and the surface, 
decreasing durability of the structure and raising maintenance costs. According to estimates, there are several hundred thousand bridges only in the United States that require significant repair and many of them have structural and strength problems and related load limitations.

\section{ALUMINUM ALLOYS - PROPERTIES}

Aluminum (Al) belongs to the group of light metals, its $2.70 \mathrm{~g} / \mathrm{cm}^{3}$ bulk density is about three times lower than in other metals commonly used in civil engineering. Aluminum and its alloys are highly treatable (plastic forming) and corrosion resistant. Thanks to the oxide coating, it is weatherproof and agent-resistant. The protection can be further increased by anodizing, i.e. electrolytic production of oxide coatings. The addition of alloy components allows for its wide use as a construction material. Hardened alloys, after a suitable thermal treatment, have strength comparable to steel, with a deadweight reduced by $2.5-3$ times. The favourable combination of relatively low weight density and high strength means that aluminum alloy structural elements can be by approx. $45 \%$ lighter than steel structures. This allows increasing the load capacity of bridges without having to replace the supporting structure and foundations and reducing the costs of investment implementation and subsequent maintenance [2,3].

Based on their basic characteristics, aluminum alloys were divided into several groups taking into account their thermal and mechanical treatability and elements being the key alloying agents. The strength properties of aluminum alloys do not only depend on the chemical composition and the type of alloying agents. The degree of mechanical hardening and thermal treatment is also important in the design process and determines the use in building structures. Thermally treated alloys, such as the 6-group alloys with magnesium and silicon as the key agents, have a yield stress comparable to carbon steel (approx. $250 \mathrm{MPa}$ ) but lower tensile strength of $200-300 \mathrm{MPa}$. The corrosion resistance of these alloys is very high and the excellent extrudability of sections leads to the unique production of long, thin-walled and closed decks in the extrusion process. These alloys are used in structural elements in which the stress level is not high, but high rigidity and resistance to corrosion and fatigue are required [2,4].

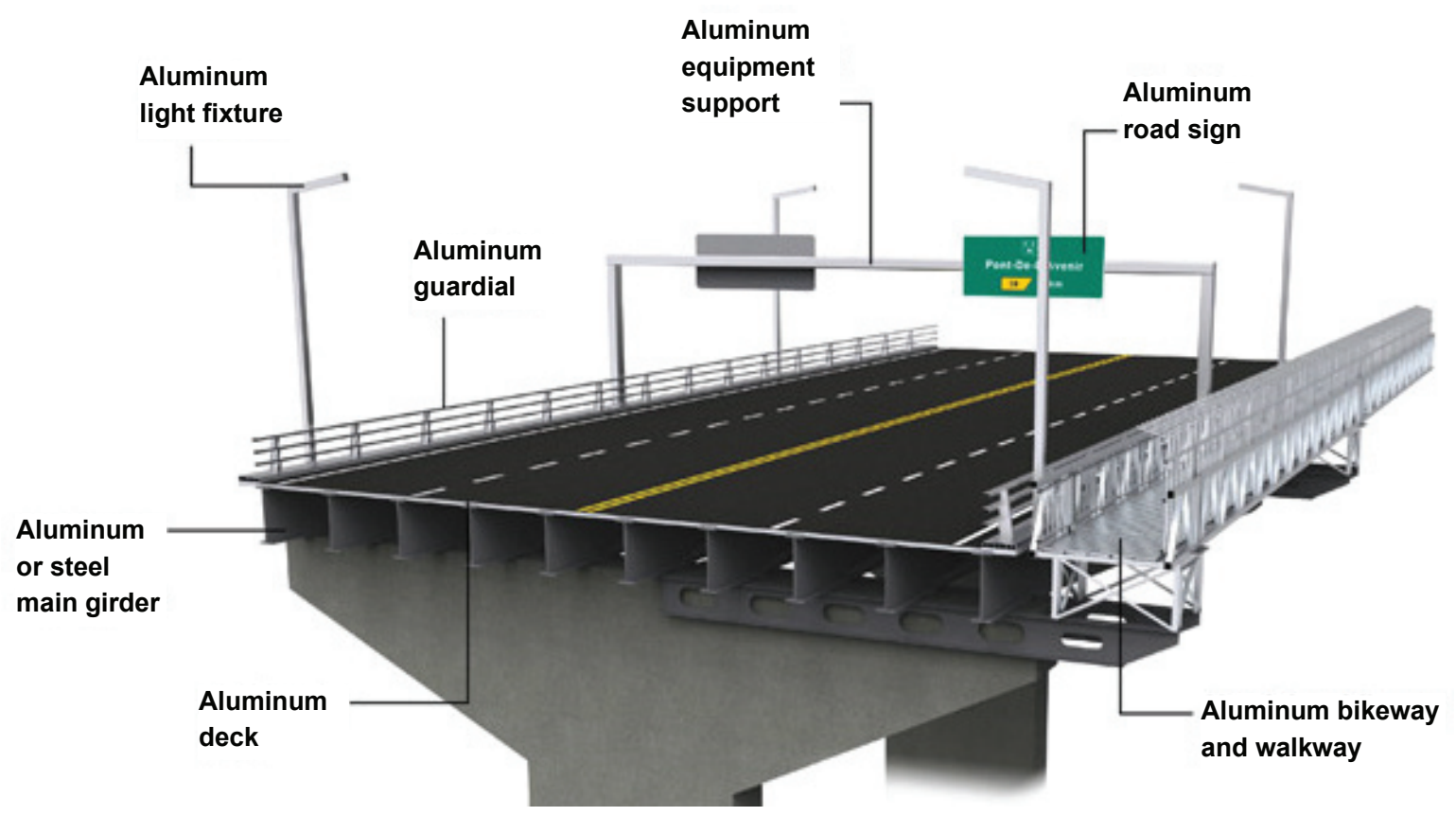

Figure 1 The use of aluminum in the construction of bridges [5] 
An important advantage is also the weldability in virtually any known method; however, the welding heat significantly reduces the strength. High mechanical parameters of the discussed materials are also observed at low temperatures which widen the range of their use on structures exposed to climatic conditions. In addition, aluminum at low temperatures is characterized by relatively high fracture toughness. Similarly to other construction material, such as structural steels $[6,7,8]$, plastic damage is observed in many aluminum alloys. Figure 1 shows the common use of aluminum structures. The subjects of the article are light aluminum alloys in bridge structures and their application for deck shaping. The main reason for the wide use of aluminum decks in bridge structures and footbridges is their low weight, durability (including resistance to corrosion) and the ease of geometric shaping. In exploited traditional bridge structures, it is decks, among all the components, (especially steel and reinforced concrete bridges) that are most exposed to destructive factors and thus are susceptible to damage.

\section{ALUMINUM DECKS AND THEIR USE}

The first aluminum bridges were probably established in 1933 in Pittsburgh (USA) and in 1946 in Massena (USA). The first aluminum drawbridge was built in Sunderland, England, already in 1948. The same year, one of the first in Europe and the first aluminum welded bridge for pedestrians was built in Poland, in Gliwice on the Kłodnica River. The structures of this type are mostly created in North America, Scandinavia and northeastern Europe [9,10].

The biggest advantages of aluminum decks include:

- $\quad$ Reduction of construction and maintenance costs and long service life;

- Reduction of costs related to traffic hold-ups;

- $\quad$ Significantly lower weight (up to $80 \%$ ) compared to steel and reinforced concrete bridges;

- Faster assembly on bridges joined in precast sections;

- $\quad$ No need for painting and repairs during operation, even in the presence of de-icing salts;

- Very good durability of epoxy surface applied on this type of decks;

- Very good parameters in terms of fatigue strength;

- $\quad$ Aluminum recycling possible.

Aluminum is commonly used for building boat bridges, footbridges and light spans of road bridges. Aluminum decks are an alternative solution for steel and reinforced concrete in existing upgraded bridge structures. Boxsection decks are most common at present. Aluminum alloy decks are used to replace worn bridge decks mainly in Europe and America [11,12,13]. Traditional bridges required inspection, maintenance and regular replacement, thus bridges had to be closed down.
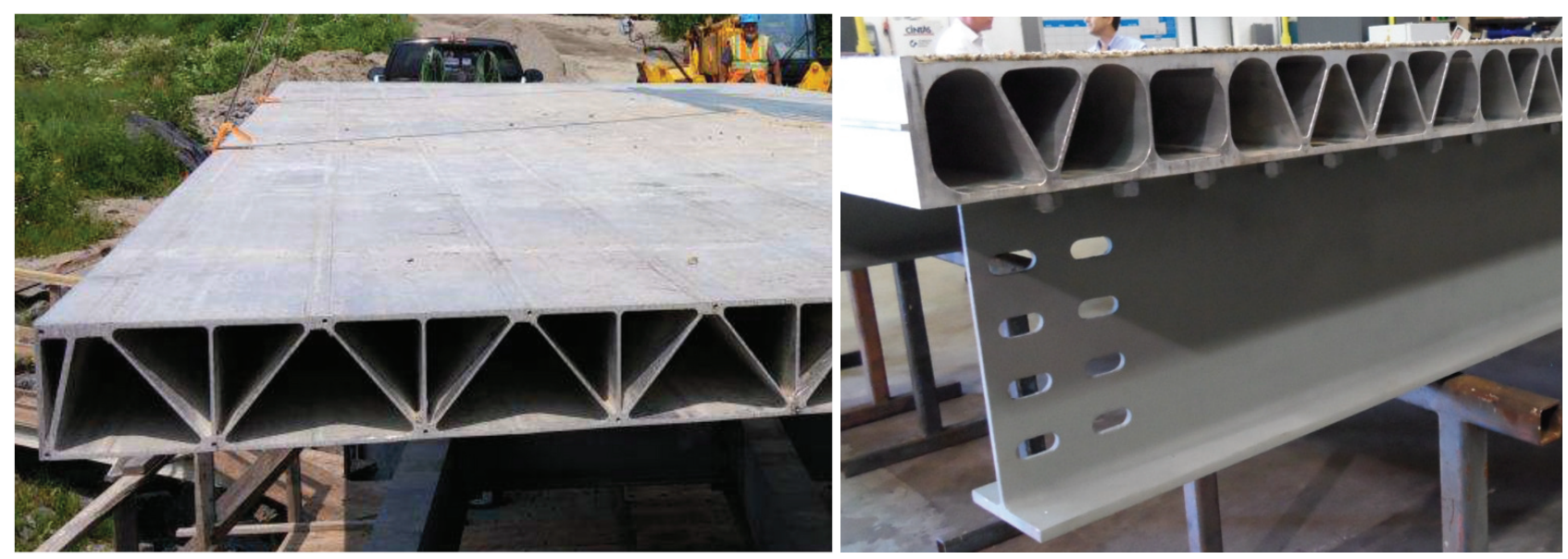

Figure 2 a) 8-inch bridge deck / b) 5-inch bridge deck [8] 
Alternative aluminum systems in the Netherlands were first used in 2003 on a movable bridge over the Haringvliet locks. Aluminum bridge decks $(3.5 \mathrm{~m} \times 1.5 \mathrm{~m})$ of a total area of approx. $600 \mathrm{~m}^{2}$ made of welded sections were applied. Examples of deck system solutions are shown in Figure 2a - 8" bridge deck was used for the St. Ambroise bridge in Quebec, Canada and Figure 2b - extruded section with a height of 5 "(127 mm) of the first generation and width of 13.624" (346 mm) with the upper wall thicker than the bottom, modelled on the 8 " section. The second generation sections were optimized for more efficient, one-sided friction welding (FSW). It has a width of 18 "(457 mm), walls of equal thickness and less welded joints.

The following are representative examples of aluminum alloy decks. Figure 3a shows the already mentioned Smithfield Street bridge in Pittsburgh. In 1934, the growing traffic intensity lead to its upgrade instead of strengthening foundations, supports and beams, the lanes and supporting beams were replaced. The mounted aluminum alloy decks with a polyester and sand surface, less than $1 \mathrm{~cm}$ thick, reduced the weight by 675 tons and increased its load capacity. In 1967, thanks to the use of an even lighter variant of aluminum beams and decks, it was slimmed down by another 100 tons and is still in good technical condition [15].
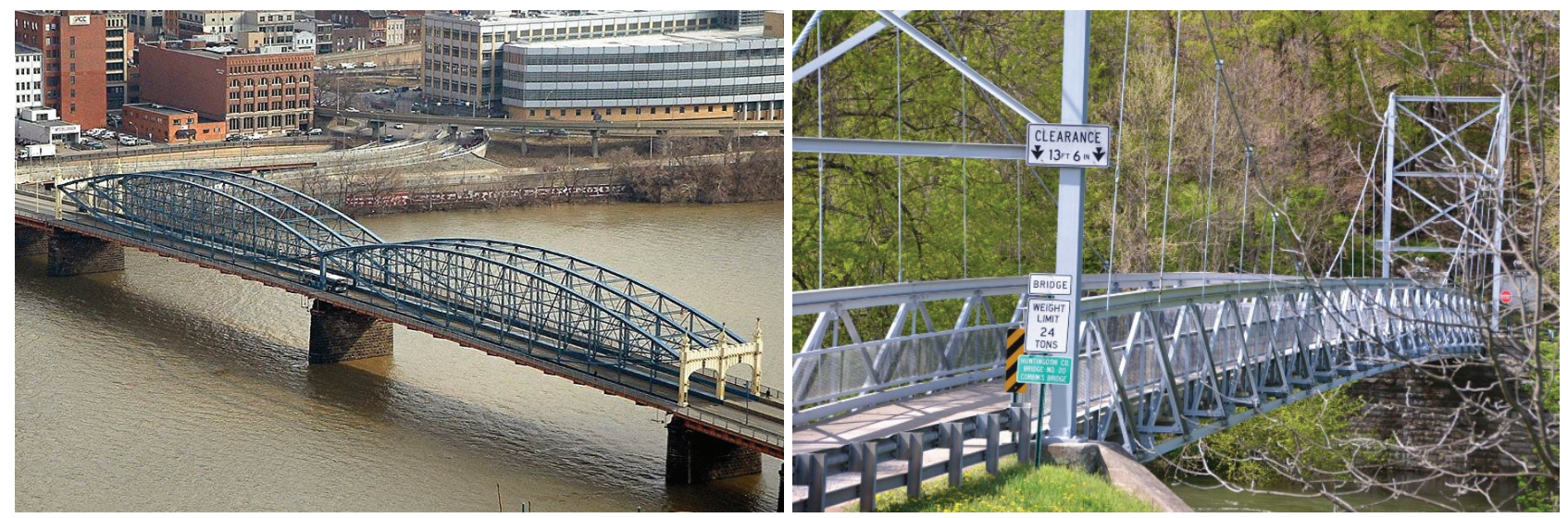

Figure 3 a) Smithfield Street Bridge in Pittsburgh [15] / b) Corbin Bridge in Huntingdon [16]

In 1996, aluminum bridge decks were used on the Corbin bridge in Huntingdon (Figure 3b), Pennsylvania. The suspension bridge connecting two sides of the city was a threat to heavy vehicles due to damage. Due to the poor foundation, the deadweight was reduced by replacing the existing superstructure with light aluminum decks with a durable polymer-sand aggregate wear surface. Nearly 100-metre bridge built in 1937 was equipped with 225 "(130 mm)-high aluminum orthotropic bridge decks, crosswise to traffic and based on 10" (250 mm) aluminum longitudinal members, which allowed increasing its load capacity from 7 to 24 tonnes.

An interesting example is the reconstruction of the bridge in 2010 at the Kambara Complex of Nippon Light Metal Co., Ltd in Japan. The bridge was not large (4.56 m long and $12.82 \mathrm{~m}$ wide), but the use of the innovative friction stir welding technology (FSW) to join individual bridge sections (Figure 4) is worth emphasizing here. The use of aluminum alloy allowed reducing the deck weight by as much as $80 \%$ compared to the same reinforced concrete deck and by $50 \%$ compared to the steel deck. The assembly itself was also facilitated due to the combination of individual elements into sections. Loads and the area needed for assembly work were reduced, which allowed using a small crane and avoiding a lane shout-down (Figure 4). In addition, it should be emphasized that aluminum is more plastic than most traditional bridge materials, which makes it an excellent material in seismic zones. The friction stir welding (FSW) technology used to join sections increases the fatigue strength of welds. They are characterised by fracture toughness and the process itself is energysaving, thus production costs can be reduced by about $30 \%$ to $50 \%$. The welding heat in FSW causes less distortions and stresses and thus the weld strength loss is lower, over 2 - 3 times higher welding speeds and faster production of decks. 

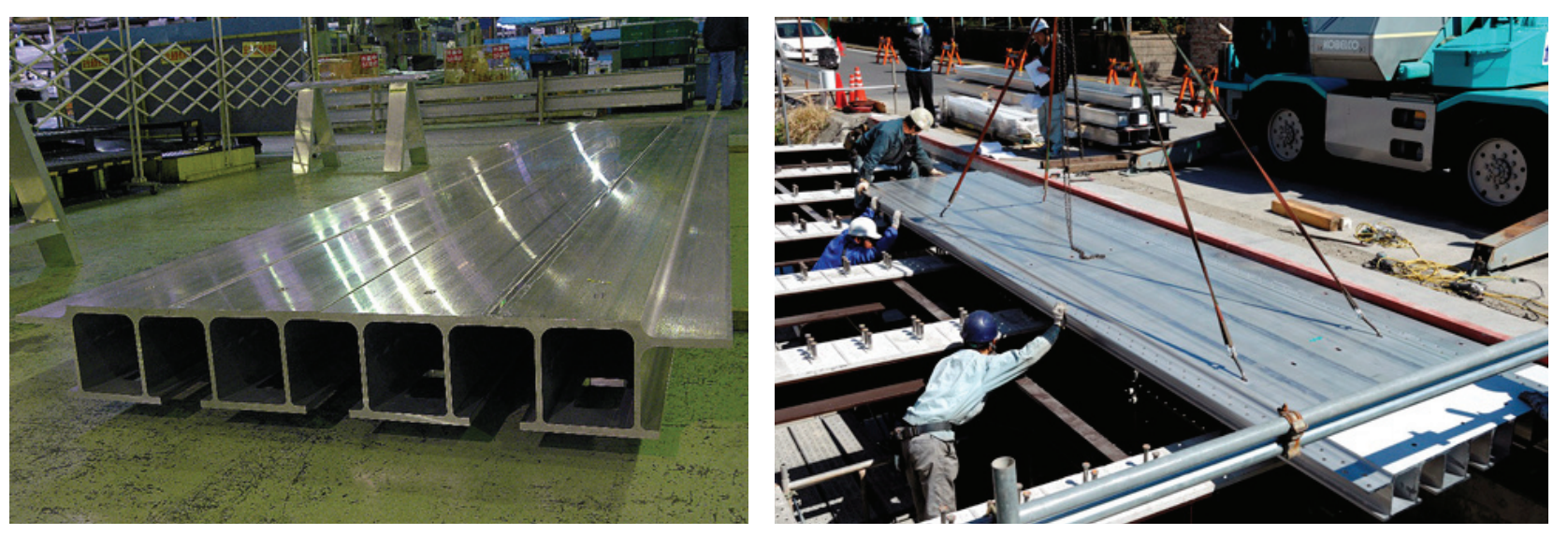

Figure 4 Kambara Chemical Bridge, view of the aluminum deck section and its assembly [17]

Another example is the expansion of an 80-year-old steel arch bridge with a span of $120 \mathrm{~m}$ near Maarssen and Utrecht in the Netherlands. The bridge over the canal and the railway line has two lanes and a shared zone on each side. One of the aspects of the upgrade was the replacement and broadening of bicycle paths from $2.5 \mathrm{~m}$ to $4.8 \mathrm{~m}$. The old ones included a concrete deck supported on steel cantilevers every $8 \mathrm{~m}$. Due to limited load capacity of cantilevers, not concrete or steel but pre-cast aluminum $16 \mathrm{~m}$ long decks allowed achieving a satisfactory width of the bicycle path (Figure 5).
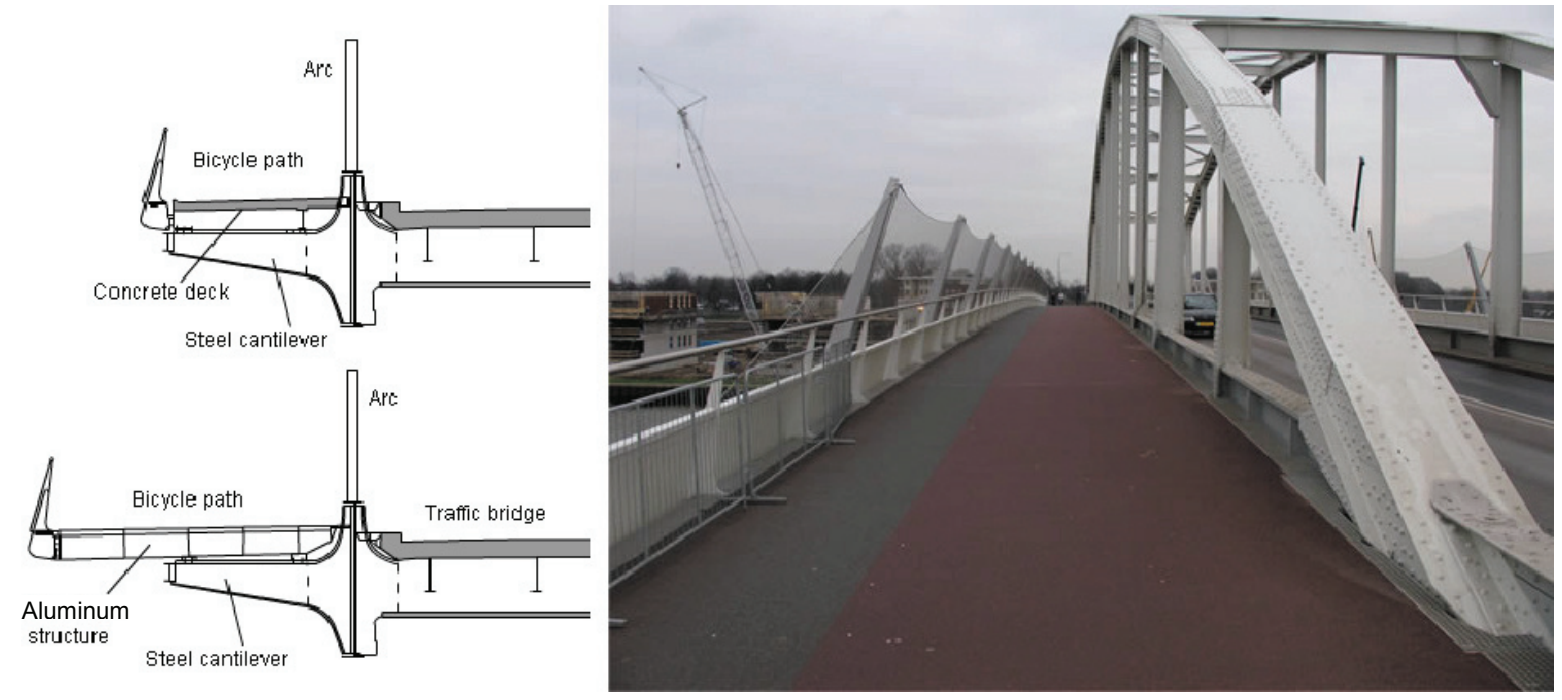

Figure 5 Bridge near Maarssen, the Netherlands [18]

\section{CONCLUSION}

Aluminum alloy products owe their growing popularity as alternative materials and renovation systems in bridge engineering to their fatigue life and corrosion resistance as well as to the low cost of assembly and subsequent maintenance of the structures. The study focuses on decks, omitting other, numerous use of aluminum alloys as elements of bridges and footbridges - beams, barriers, handrails, deck gratings, etc. The currently existing aluminum structures, although not requiring any maintenance, corrosion protection or repair, still show excellent technical condition. Therefore, the use of aluminum alloys for deck and superstructure replacement is an interesting solution allowing the expansion of old bridges using the existing support structure, increasing load capacity, construction in difficult terrain, on poor ground or when facing problems with the implementation and structure shut-down for works. 
An important asset is also the fact that aluminum is an environmentally friendly material, the so-called "green" metal. Although the extraction process itself is energy-consuming and expensive, it still can be referred to as ecological material, reprocessable with virtually no loss of mechanical properties. The aluminum alloy products, widely applied in civil engineering, contain a considerable amount of recycled materials and they can be easily and profitably recycled. This translates into lower energy consumption and reduction of pollution associated with aluminum production.

\section{REFERENCES}

[1] SIWOWSKI, T. Procedura oceny zmęczenia pomostów metalowych w obiektach mostowych (Fatigue assessment procedure for metal decks in bridge structures). Drogi i Mosty. 2012. no. 1, pp. 53-79.

[2] SIWOWSKI, T. Drogowe mosty aluminiowe - wczoraj, dziś i jutro (Aluminum road bridges - yesterday, today and tomorrow). Drogi i Mosty. 2005. no. 1, pp. 39-74.

[3] KISSEL, J.R., and FERRY, R.L. Aluminum Structures: A Guide to Their Specifications and Design, 2nd ed., New York: John Wiley \& Sons, 2002. p. 544.

[4] KWIATKOWSKI T. Charakterystyka i wykorzystanie stopów aluminum oraz taśm węglowych w budownictwie (Characteristics and use of aluminum alloys and carbon fibre strips in civil engineering), Scientific Papers of the Częstochowa University of Technology. Budownictwo. 2011. vol. 167, no. 17, pp. 112-118.

[5] Aluminum, Infrastructure and Bridges, [online]. [viewed 2019-03-10]. Available from: https://aluminum.ca/en/aluminum/infrastructure-and-bridges.

[6] KOSSAKOWSKI, P. G. Stress modified critical strain criterion for S235JR steel at low initial stress triaxiality, Journal of Theoretical and Applied Mechanics. 2014. vol. 52, iss. 4, pp. 995-1006.

[7] KOSSAKOWSKI, P. G. An analysis of the Tvergaard parameters at low initial stress triaxiality for S235JR steel. Polish Maritime Research. 2014. vol. 21, iss. 4, pp. 100-107.

[8] KOSSAKOWSKI, P. G. Experimental determination of the void volume fraction for S235JR steel at failure in the range of high stress triaxialities. Archives of Metallurgy and Materials. 2017. vol. 62, iss. 1, pp. 167-172.

[9] MACILLO, V. Special joint systems for aluminum structures: experimental tests and numerical models. PhD thesis, Università degli Studi di Napoli Federico II, 2013.

[10] KWIATKOWSKI, T. Aluminum w nowoczesnych konstrukcjach budowlanych (Aluminum in modern civil structures), Scientific Papers of the Częstochowa University of Technology. Budownictwo. 2012. vol. 168, no. 18, pp. 108-115.

[11] SALEEM, M., MIRMIRAN, A., XIA, J. and MACKIE, K. Experimental evaluation of aluminum bridge deck system. Journal of Bridge Engineering. 2012. no. 17, pp. 97-106.

[12] ZHANG, Y., QIU, J. F. and BAI, H. Application and research progress of aluminum alloy bridge decks. Key Engineering Materials. 2012. vol. 517, pp. 763-770.

[13] CHOO, C.C., PEIRIS, A. and HARIK, I.E. Development and Deployment of Aluminum Bridge Decks. Research Report. Lexington: Kentucky Transportation Center, 2012. p. 44.

[14] Aluminum Bridge Decking, Advancements \& Applications, LBFoster AlumaBridge [online]. [viewed 2019-03-01]. Available from: https://agtr.com/system/files/file manager/lundi am osberg.pdf.

[15] Smithfield Street Bridge, [online]. [viewed 2019-02-05]. Available from: http://www.brooklineconnection.com/history/Facts/Smithfield.html.

[16] Historic and Notable Bridges of the U.S., [online]. [viewed 2019-03-21]. Available from: http://bridgehunter.com/pa/huntingdon/317212042830200/.

[17] Bridge using aluminum road bridge plate decks constructed firstly in Japan. [online]. Date 2011-04-20 [update]. [viewed 2019-02-25]. Available from: https://www.nikkeikin.com/news/whatsnew/post 23.html.

[18] Netherlands 17: The route to De Haar Castle. [online]. Date 2017-06-24 [update]. [viewed 2018-01-13]. Available from: https://juststepsideways.com/2017/06/24/netherlands-17-the-route-to-de-haar-castle/. 